Becoming Worthy of What Happens to Us

Art and Subjectivity in the Philosophy of Gilles Deleuze

Levin, Kasper

Published in:

Art and Identity

Publication date:

2013

Document version

Early version, also known as pre-print

Citation for published version (APA):

Levin, K. (2013). Becoming Worthy of What Happens to Us: Art and Subjectivity in the Philosophy of Gilles

Deleuze. In T. Roald, \& J. Lang (Eds.), Art and Identity: Essays on the Aesthetic Creation of Mind (pp. 133-165).

Brill | Rodopi. Consciousness, Literature and the Arts Vol. 32 


\title{
VII. Becoming Worthy of What Happens to Us: Art and Subjectivity in the Philosophy of Gilles Deleuze
}

\author{
Kasper Levin
}

\author{
Roskilde University
}

Aesthetics traditionally lends itself to a double meaning. On the one hand, it is often referred to as a theory of art by which we can reflect on our experiences with different material forms of expression; on the other hand, aesthetics also refers to a more general theory of sensibility, as the fundamental ground for subjective experience. In the context of this book's themes of art and identity, aesthetic dualism is central, because it immediately forces us to presuppose, in the analysis of the role of art, a separation of the subjective level of experience and the objective conditions for experience, as such.

Philosophically, aesthetic dualism goes back to Immanuel Kant's distinction between the analysis of a transcendental aesthetic (Kant 1781) and aesthetic judgment (Kant 1790). However, due to the pervasiveness of Kantian thought aesthetic dualism does not restrict itself to the realm of philosophical aesthetics. This dualism leads to a common claim inherent in many approaches to art: that works of art must be considered as representations, expressing or signifying an identity underlying human subjectivity.

To name a few generalized examples, in psychoanalysis aesthetic dualism is inherent in the understanding of artworks as representations of unconscious objects or desires (e.g., Freud 1910; Segal 1952; Wollheim 1987). In neuropsychology the aesthetic dualism is inherent in the claim that art represents neural laws of the brain (Zeki 2004), and in phenomenology it is inherent in the conception of art as a rep- 
resentation of the intentionality of subjective experience (e.g., Ingarden 1965). In other words, subjectivity is presupposed in the understanding of art. Though many exponents of various disciplines in philosophy and psychology emphasize the significance of art to subjectivity, most often the model of art as a representation or reflection of the world reduces art to an appendix to subjective thought.

From my point of view, the presupposition of a subjective identity as a primary condition in art is problematic because it reduces the genuinely creative or productive relationship between art and subjectivity to an instance of representation, reference, or reproduction. By presupposing subjectivity in the understanding of art, the productions in art are subjugated to general categories of subjective thought, reducing art to a reflection of thought rather than a production of it. In my view, this perspective remains blind to the role of art as a genetic or productive force in subjectivity.

The intensive engagement with art and aesthetics in the works of the French philosopher Gilles Deleuze is often portrayed as a means of dissolution or a fundamental break with the discourse on subjectivity in both its psychological and philosophical expositions. According to Deleuze, what is central to art is not an exploration of emotions or representations of a world of perceptions, but rather the production of sensations as the genetic principle immanent to subjectivity. The claim that art does not represent, but rather creates or expands the world we experience through sensations, means that the question of 'art' and 'identity' is not an apprehension of a harmonious accord between the subjective being and art, but rather an expression of a fundamental dissension or rift. Thus, through the function of art we are constantly reminded that the subjective acts of thinking, feeling, seeing, or hearing cannot be presupposed. As Deleuze argued, we do not experience art but we become subjectivities through it. Often this radical aesthetic element of Deleuze's philosophy is reduced to a destructive dismantling of personal identity, exposing the contradictory elements and internal oppositions of subjectivity.

Indeed, a genuinely non-human element of thought, beyond the established notions of subjectivity and identity, does constitute a central force in Deleuze's approach to art. However, as I suggest, his radical dismantling of subjectivity through art should not be considered as the end of subjectivity, but rather as an opening up of a crea- 
tive domain in our constant involvement with the production of subjectivity as a way of organizing thought.

Deleuze's famous notion of the 'Body without Organs' (taken from the French poet Antonin Artaud) as the means of escaping the subjective organization of thought, is perhaps the most renowned example of a radical non-human element in his thinking related to a specific work of art. However, this notion must not be misunderstood as a rejection of the subjective element in art. On the contrary, the dissolution of subjectivity in Deleuze's philosophy is always immanent to a productive endeavor, a launching of new organizations of thought. It is in this context that Deleuze calls for a will to listen to and learn from art. As I shall argue, what is produced in Deleuze's writings is not a negative rejection of subjectivity, but an affirmation of life through art. It is this affirmative openness or will to learn from works of art that makes Deleuze's approach to the relation between art and subjectivity a unique attempt to place art at the center of thought. Nevertheless, this rather existential perspective in Deleuze's work is often ignored.

By following a trajectory from Deleuze's critique of Kantian aesthetics and his own aesthetic notion of a transcendental empiricism to his influential engagement with the works of the painter Francis Bacon and the writer Marcel Proust, I will analyze Deleuze's work as an exemplary case of placing art at center of thought and consequently at the core of subjectivity.

\section{The Reversal of Kantian Aesthetics}

Philosophically, the question of subjectivity and art in Deleuze's work is closely related to a rigorous rethinking of the relationship between sensation and thought, which makes aesthetics a central topic of his writings. As seen in his reading of Kant, what Deleuze is pushing for is the possibility of uniting the duality between the theory of sensibility as the form of possible experience (i.e., the transcendental aesthetics) and the theory of art as reflection of real experience (i.e., aesthetic judgment) (Smith 1996). On the one hand, the a priori forms of space and time constitute the conditions for the possibility of our experience and cognition, as such (the transcendental aesthetic in Kritik der Reinen Vernunft [1781]); on the other hand, aesthetic judgments based on the feelings of pleasure and pain are subjective and hold no immediate universal validity. Thus, in Kant's transcendental philosophy, the 
relationship between sensation and thought is approached dualistically. In Kritik der Urteilskraft (1790), one of the challenges for Kant is how to account for the possibility of universal principles for aesthetic experiences. Kant's answer is based on a presupposition of a universal relationship between the faculties of cognition.

While the transcendental aesthetic forms the necessary condition for the given object and the universal possibility of objective experience, the universal principle of aesthetic judgment, as the subjective reflection on real experience, is what Kant calls a 'sensus communis aestheticus,' or aesthetic common sense. In Deleuze's reading of Kant's aesthetics, the presupposition of common sense represents what he calls a "dogmatic image of thought" that must be overcome to reveal the real relationship between sensation and thought.

\section{Critique of the Aesthetics of Common Sense}

According to Kant, the external senses of the subject are passive receivers of intuitions of a given object, and the recognition of a sensed object presupposes an active synthesis or accordance of the internal faculties: understanding, reason, and imagination. Each faculty has its own way of acting toward a given object, but in order to recognize an object a faculty must find its given object identical to that of another: the object that can be sensed must be identical to what can be imagined, remembered, conceived, etc. The synthesis of an intuited object of sensation and the cognitive faculties is possible due to the imagination's creation of a transcendental schema combining the formless manifold of sensuous intuitions according to the a priori concepts or categories. The result of the different faculties' total relation to the transcendental form of a given object is what Kant refers to as 'sensus communis,' which is not to be understood as a common understanding or a psychological disposition but as the universal condition for our judgments.

In logical scientific judgment and practical moral judgment, the schematization of the imagination is legislated respectively by the concepts of understanding and reason as the pure form of desire. Aesthetic judgment, however, is described by Kant as a result of the effect of the subjective common sense, which does not mean a psychological or empirical "outer sense, but [...] the effect arising from the free play of our powers of cognition" (Kant 1790/1987: 87). Because the aesthetic common sense is a free accord of the cognitive faculties- 
meaning that neither understanding nor reason has legislative poweraesthetic judgment cannot be determined by a concept, but remains the subjective feeling of pleasure or pain. This is also why Kant described aesthetic pleasure as disinterested, since it is neither guided by a speculative or practical interest. However, this does not imply that the imagination is independent from understanding in aesthetic judgments of the beautiful:

\footnotetext{
Only where the imagination is free when it arouses the understanding, and the understanding, without using concepts, puts the imagination into a play that is regular [i.e., manifests regularity], does the presentation communicate itself not as thought but as the inner feeling of a purposive state of mind. (Kant 1790/1987: 162)
}

In other words, the feeling of pleasure related to an aesthetic judgment of beauty is not produced by the empirical or sensuous encounter with an object, but is the effect of the pure representation of a universal subjective state of mind. In this way, the common sense also designates the result of an a priori unity of the cognitive faculties, without which knowledge would not be communicable and universal. When we feel pleasure from experiencing a beautiful piece of music or a painting, we assume, in principle, that our pleasure is communicable to everyone through the universal identity of subjectivity. Similarly, when we say that a work of art is beautiful, the objectivity we claim is not related to the conditions to which an object must be subject, but to the mere reflection of an inner harmony or free accord between the faculties as the condition for subjectivity, as such. As a universal principle for the subjective judgment and synthesis of knowledge, common sense is also what relates the transcendental conditions for the true, the good, and the beautiful in Kant's philosophy.

In this way, aesthetic experiences and works of art are described as acts of recognition and representation in the subjective relation between sensation and thought. This relationship not only presupposes an objective identity given to the faculties as recognition (i.e., transcendental aesthetic), but also an identity of the subject that unites the faculties in a harmonious accord in the effect of common sense (i.e., aesthetic judgment). In different terms, the a priori common sense in Kant presupposes an accord between the unity of the consciousness and the wholeness of the object. Deleuze questioned this assumption and asked: 
[Is] it sufficient to assume this free accord, to suppose it a priori? Must it not be, on the contrary, produced in us? That is to say: should aesthetic common sense not be the object of a genesis, of a properly transcendental genesis? (1963/1984: 50)

As Deleuze pointed out, Kant's aesthetics of beauty does not leave room for a genetic or creative element in the relations between sensation and thought. The presumption of recognition as a ground for the external relations of thought reduces the act of thinking to a question of representation of the already given. Kant described the spatiotemporal relations in the schema of the imagination, which connects passive sensuous intuitions to the active faculties, as a mystery, or "an art concealed in the depths of the human soul, whose real modes of activity nature is hardly likely ever to allow us to discover" (Kant 1781/1929: 183). In Kantian aesthetics of beauty, encounters with works of art remain cognitive representations of an already given harmony which is never explained but must be assumed.

According to Deleuze, however, the presupposition of a common sense as ground for the aesthetic experience presents a problem in terms of explaining the reproduction of sensuous intuitions by the imagination, because the common sense necessarily presupposes an inaccessible or hidden external harmony in sensible nature which makes possible the identification or recognition of concepts. As a result, intuition and concept-and, consequently, sensation and thought - constitute a problematic duality in the Kantian system, which does not account for aesthetics or sensation as genetic or creative elements of thought.

In his early main work, Différence et Répétition, Deleuze wrote:

Such a duality refers us back to the extrinsic criterion of constructability and leaves us with an external relation between the determinable (Kantian space as pure given) and the determination (the concept in so far as it is thought). (1968/2004: 220)

Kant's internalization of the subject-object relation in the presupposed common sense is based on an assumption of an already given identity of the subject, and remains blind to this external difference between what is determinable in thought and the act of thinking in determinant concepts. For Kant, difference remains empirical and, as such, suspended outside the transcendental relations of the faculties and unobtainable by the ideas of reason. The schematism of the imag- 
ination therefore neither legislates nor creates the harmony between intuition and concept, but merely adapts and reproduces it under the given accord between concepts of understanding and ideas of pure reason. On this account, Deleuze accused Kant of reducing the transcendental - that is, the conditions of possibility - to a question of adapting to or reproducing an already given aesthetic common sense. "In so far as the practical finality of recognition lies in the "established values", then on this model the whole image of thought as Cogitatio natura bears witness to a disturbing complacency" (171). Deleuze objected to an image of thought based on "the idea of a good nature of the faculties" (Deleuze 1963/1984: 21) and to the act of thinking as a natural or voluntary exercise that formally leads to truth. Like Friedrich Nietzsche, Deleuze criticized Kant for leaving out the question of values in his critical project, and pointed to the model of recognition in the common sense as a dogmatic image of thought, blind to its own origin in the already established. This becomes particularly apparent in the judgment of beauty, because the harmony cannot be ascribed to a legislating faculty, but must be assumed instead as a disinterested reflection of a universally well-proportioned subjectivity a priori. Kant's aesthetics remains dualistic, separating the objective conditions of possibility exposed in the transcendental aesthetic from the subjective feeling involved in aesthetic judgment.

In Kant's theory of the sublime, however, Deleuze found an opening toward another basis for aesthetics that goes beyond the presupposition of subjective identity, representation, and recognition.

\section{The Sublime: Toward a Genetic Principle of Aesthetics}

Kant simply described the sublime as large in its absolute sense or "large beyond all comparison" (1790/1987: 103). The sublime denotes the wholeness that through its magnitude is not available to the reconstruction of the faculties. Contrary to the experience of beauty grounded in the higher pleasure of the free and indeterminate harmony, the experience of the sublime is grounded in an unpleasurable inadequacy of the faculties due to the limited powers of the imagination. The precondition for the experience of aesthetic magnitude is, on the one hand, the apprehension ("apprehensio") of the imaginationthe inner partial presentations from the manifold or formless sensuous intuition - and, on the other hand, the simultaneous comprehension ("comprehensio aesthetica") of the successively apprehended parts, 
the mental grasping of the manifold over time in a representation of a unity of intuition. But the encounter with the whole of an absolute magnitude creates problems in this progressive synthesis.

\footnotetext{
Apprehension involves no problem, for it may progress to infinity. But comprehension becomes more and more difficult the farther apprehension progresses, and it soon reaches its maximum, namely, the aesthetically largest basic measure for an estimation of magnitude. (Kant 1790/1987: 108)
}

Our comprehension, Kant argued, has a limited range beyond which representation of the progression of parts apprehended becomes impossible to imagine. The foundation for aesthetic experience of the sublime is a feeling of unpleasure due to this inadequacy of the power of the imagination. Only the experience of "crude nature" in its incomprehensible magnitude serves as an appropriate example of the sublime. Faced with the immensity of nature's formless, absolute magnitude the imagination reaches its own limit. The comprehension of any appearance in the absolute whole of intuition is imposed on us from the law of reason, "which knows no other determinate measure that is valid for everyone and unchanging than the absolute whole" (114).

So, while the feeling of the beautiful represents a harmony between the faculties of understanding and imagination, the feeling of the sublime expresses a dissension between the demands of reason and the power of imagination. In other words, the sublime denotes the impossibility of an accord between imagination and reason in the comprehension of the rational idea of sensible nature as an infinite or absolute whole. Thus, the unpleasurable inadequacy in the sublime reflects the inaccessibility of the absolute rational ideas to the sensuously dependent imagination. It is not a psychological discrepancy, but an inadequacy in sensible nature, as such, or what Kant described as an encounter with a "supersensible substrate" (Kant 1790/1987: 112). Nevertheless, the feeling of the sublime is associated with a certain transcendental genesis or creation.

\footnotetext{
In order for the mind to be attuned to the feeling of the sublime, it must be receptive to ideas. For it is precisely nature's inadequacy to the ideas - and this presupposes both that the mind is receptive to ideas and that the imagination strains to treat nature as a schema for them - that constitutes what both repels our sensibility and yet attracts us at the same time, because it is a dominance [Gewalt] that reason exerts over sensibility only for the sake of ex-
} 
panding it commensurately with reason's own domain (the practical one) and letting it look outward toward the infinite, which for sensibility is an abyss. (Kant 1790/1987: 124)

Like common sense in the judgment of beauty, the sublime is founded on subjective principles. But the feeling of the sublime more urgently requires a genetic principle that is associated with the creation or development of a culture. This does not mean that the sublime is something produced by culture or imposed by society; it is, rather, the natural capacity for a feeling for (practical) ideas, a moral sense that marks the fundamental relationship between nature, man, and the creation of a culture. The subjective feeling of the sublime is not connected to truth as an abstract idea, but rather to the practical destination of our faculties as moral beings. In this way, the discord or dissension between imagination and reason - the precondition for the sublime-is also the genesis of a new harmony.

\footnotetext{
For though the imagination finds nothing beyond the sensible that could support it, this very removal of its barriers also makes it feel unbounded, so that its separation [from the sensible] is an exhibition of the infinite; and though an exhibition of the infinite can as such never be more than merely negative, it still expands the soul (Kant 1790/1987: 135).
}

Confronted with its own limit by the demands of reason, the imagination goes beyond this limit in the sense that it presents to itself the fact that there is something in sensible nature that cannot be represented in imagination. Empirically the sublime is inaccessible to the faculties, but expresses itself as a transcendental engendering of the genuinely new, or, rather, that which can only be imagined. In this way, "[t]he sense of the sublime is engendered within us in such a way that it prepares us for the advent of the moral law" (Deleuze 1963/1984: 52). In other words, the analysis of the sublime introduces a final discordant harmony between the faculties that is not presupposed, but is the result of a transcendental and creative exercise of the faculties. By introducing this element of creativity into his system, Deleuze argued, Kant managed to go beyond the dogmatic image of thought toward a genetic principle of aesthetics.

However, since the essence of Kant's philosophical system, running through his three major critiques, is still founded predominantly on the dogmatic model of recognition and common sense as a given identity in the relation between the transcendental and the empirical, 
"it can be said that Kant's critical revolution changes nothing essential" (Deleuze and Guattari 1972/1983: 48). But as Deleuze pointed out, the analysis of the sublime presents a form of thinking fundamentally different from the dogmatic image of thought. The analysis of the sublime in Kritik der Urteilskraft is an opening toward a genetic relation between sensation and thought. On this basis, Deleuze interpreted Kant's third critique as the genetic foundation for the previous two, since it "uncovers a deeper free and indeterminate accord of the faculties as the condition of the possibility of every determinate relationship" (Deleuze 1963/1984: 68). Through this reversal of Kant, Deleuze suggested that the element of sensation is not preconditioned by a priori common sense or cognitive recognition, but is rather the genesis from a fundamental encounter of differential relations between the faculties. From this perspective, Deleuze's critique of Kant also overcomes aesthetic dualism between the aesthetics of possible experience and that of real experience, between the transcendental and the empirical. It is from this perspective that Deleuze called his position transcendental empiricism - an image of thought in which art is considered a necessary productive element.

\section{Transcendental Empiricism and Art}

In several texts, Deleuze $(1962,1968,1972)$ illustrated the difference that separates the dogmatic and the genetic relation between sensation and thought by referring to a passage in Plato's The Republic (c. 380 B.C) that lays out two different accounts of perception.

\footnotetext{
Take our perceptions, then. I can point to some of these which do not provoke thought to reflect upon them, because we are satisfied with the judgment of the senses. But in other cases perception seems to yield no trustworthy result, and reflection is instantly demanded. (Plato c. 380 B.C./1945: 238239)
}

Plato's description of unprovoked judgments is an example of what Deleuze, in relation to Kant's general analysis of cognition, described as a "disturbing complacency" of thought and that he found to be dogmatic. But those cases where "reflection is instantly demanded" mark the genetic principle of thought, to be found in Kant's analysis of the sublime. On this background, Deleuze described the sublime as a fundamental encounter that calls for thinking: 
Something in the world forces us to think. This something is an object not of recognition but of a fundamental encounter. What is encountered may be Socrates, a temple or a demon. It may be grasped in a range of affective tones: wonder, love, hatred, suffering. In whichever tone, its primary characteristic is that it can only be sensed. In this sense it is opposed to recognition. In recognition, the sensible is not at all that which can only be sensed, but that which bears directly upon the senses in an object which can be recalled, imagined or conceived. (1968/2004: 176)

The conditions for subjective thought are not to be found in what is possible to represent in general, but rather in the real encounters with the differential or contradictory elements of sensation - to quote Plato, those encounters "when perception yields a contradictory impression, presenting two opposite qualities with equal clearness" (239).

Contrary to the Kantian image of thought, presupposing the identity of truth and the good as pre-established recognizable subjective givens in aesthetic experience, Deleuze pointed to a fundamental difference in aesthetic experience as the precondition for every phenomenon and production of subjectivity:

\footnotetext{
Difference is not diversity. Diversity is given, but difference is that by which the given is given, that by which the given is given as diverse... Every phenomenon refers to an inequality by which it is conditioned. Every diversity and every change refers to a difference which is its sufficient reason. Everything which happens and everything which appears is correlated with orders of difference: difference of level, temperature, pressure, tension, potential, difference of intensity. (1994/1998: 280)
}

In this way, no general transcendental conditions of possibilities can be given a priori, but must always be the result of a genesis or transcendental production in sensible nature. It is from this perspective that Deleuze related his own philosophy to empiricism, not in the traditional sense as a way of explaining all knowledge as induced by experience, but rather empiricism as a question of the production of subjectivity. In his book, Empirisme et subjectivite (1953), on the philosophy of David Hume, Deleuze criticized the traditional textbook definition of empiricism as defined by the Kantian tradition, because it mistakenly interprets knowledge as the most important element for empiricism. Knowledge, argued Deleuze, 
particular, does not have this univocal and constitutive aspect that we give it. (1953/1991: 107-108)

According to Deleuze's reading of Hume's empiricism, human nature and subjectivity are not given as such, but are always constituted in the given, i.e., in a collection of ideas or in the imagination. As Deleuze pointed out, the important questions for empiricism are: "how does the mind become a subject? How does the imagination become a faculty?" (23). To the empiricist, ideas are not representations of a universally given system, but are the result of differential external relations in the production of subjectivity. In Hume, Deleuze found this in the relationship between atomism of distinct differential ideas (nature) and the transcending principles of associationism (human nature, subjectivity). Rather than presupposing a privileged harmony as a precondition for meaningful and rational representations, Hume claimed an atomic structure for our ideas by showing how the idea in itself is a complete whole with no reference to other ideas. The relationship between singular and differential ideas occurs as a result of a psychological habit in human nature, not as a result of the way the ideas are given in themselves. Hume's primary example is causality, which, according to him, does not refer to the nature of how an idea is given in itself, but is rather the result of a habit. In other words, habit "determines the imagination to make a transition from the idea of one object to that of its usual attendant, and from the impression of one to a more lively idea of the other" (Hume 1888/1978: 170). The concept 'idea' should here be understood equivocally as both the sense impression of an object and the linguistic understanding of it. This equivocality of the idea makes it possible for the empiricist to insert habit and the laws of association as mediating principles between the meaningless nature of distinct differential relations and the structure of the subjective world of intentionality and meaning (Diderichsen 2001). Rather than presupposing a given identity represented in ideas, empiricism takes its point of departure in the differential relations between a nature of meaningless causal associations, on the one side, and a meaningful human culture of habits or structure, on the other. Between the immediate lifeworld of the thinking subject and the physical world, empiricism inserts the equivocal nature of human sensation as a mediating principle (Diderichsen 2001).

Consequently, in Deleuze's interpretation, the primary question for empiricism concerns the genesis of subjectivity, or how the consti- 
tution of a world of meaning and culture is possible on the basis of immanent principles in nature. As opposed to Kant's transcendental idealism of common sense, empiricism does not presuppose subjectivity and the rational structure of the world as a given, but rather seeks the conditions of possibility of thought in the chaotic multiplicity of relations external to subjective meaning and ideas. "The depth of the human mind is indeed delirium, or - same thing from another point of view - chance ${ }^{1}$ and indifference" (Deleuze 1953/1991: 23). In this perspective, human subjectivity is constituted as the practical structuring and affecting of the chaotic multiplicity of singular and differential ideas. On this account, Deleuze considered empiricism to be a pluralistic theory of understanding and a critique of representation -in essence a thinking that does not suspend or reduce differential relations to an impure element outside the act of thinking:

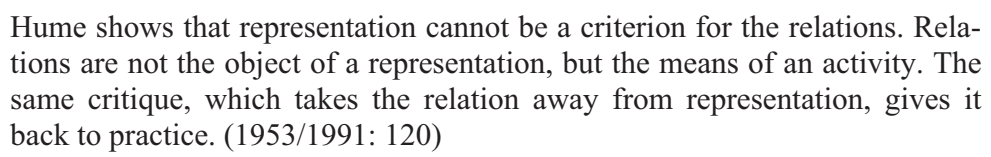
tions are not the object of a representation, but the means of an activity. The same critique, which takes the relation away from representation, gives it back to practice. $(1953 / 1991: 120)$

This is also why the primary object for Hume is not knowledge or truth, but rather subjectivity as the unfolding of practical ideas for moral, historical, and political questions-" "Hume is above all a moralist, a political thinker, and a historian" (Deleuze 1953/1991: 33). It is through this interpretation of Hume and empiricism that Deleuze's introduction of the notion of a transcendental empiricism should be understood as a pluralistic thinking that does not presuppose general ideas of already established external relations as a condition for possible experience. In this image of thought, aesthetics is not a question of identifying the conditions of possibility for a harmonious or sensible thought, or the feeling of pleasure related to the reflection of subjectivity; it is, rather, a question of seeking the conditions for thought and ideas in the multiplicity of differential relations directly in the sensible.

It is strange that aesthetics (as the science of the sensible) could be founded on what can be represented in the sensible. True, the inverse procedure is not

\footnotetext{
${ }^{1}$ I have corrected a typographical error in the English text, in which the French word "hasard" erroneously is translated as "change."
} 
much better, consisting of the attempt to withdraw the pure sensible from representation and to determine it as that which remains once representation is removed... Empiricism truly becomes transcendental, and aesthetics an apodictic discipline, only when we apprehend directly in the sensible that which only can be sensed, the very being of the sensible: difference, potential difference and difference in intensity as the reason behind qualitative diversity. (Deleuze 1968/2004: 68)

Deleuze's notion of aesthetics is transcendental insofar as its origin is not given in a transcendent relation between subject and object, and empirical to the extent that it seeks the explanation of ideas in immanent principles given in the multiplicity of differential relations of sensation. By not subjugating sensation to a model of representation in the sensible, it reveals itself as a necessary quantitative force behind the production of subjectivity and in this way aesthetics becomes an apodictic or necessary discipline for thought. There are no general conditions of possibility for the object of sensation, but only a mutual determination of the object in the encounter between contradictory forces of sensation.

\footnotetext{
We will never find the sense of something (of a human, a biological or even a physical phenomenon) if we do not know the force which appropriates the thing, which exploits it, which takes possession of it or is expressed in it. (Deleuze 1962/1983: 3)
}

Sensation is in itself a symptom of an encounter that gets its meaning from the existing dominant forces. The act of thinking is neither reflection, nor contemplation, nor representation, but a production of forces. Deleuze's account of the relation between sensation and thought resonates heavily with the ontology of Nietzsche and his notion of the 'will to power' as a principle for the synthesis of forces (cf. Deleuze 1962). Force is the result of a differential relation or encounter between opposing forces (i.e., intensities), which are the fundamental genetic condition for thought. Like Nietzsche, what Deleuze suggested is that objects are expressions of quantitative difference conditioned by immanent relations of force. Subjective qualities of perception and affection originate and are conditioned by intensities of differential relations of sensation. He claimed that "The privilege of sensibility as origin appears in the fact that, in an encounter, what forces sensation and that which only can be sensed are one and the same thing" (Deleuze 1968/2004: 182), and that "[T]he two senses of 
the aesthetic become one, to the point where the being of the sensible reveals itself in the work of art, while at the same time the work of art appears as experimentation" (82). In uniting the transcendental aesthetics of objectivity and the empirical pluralism in the production of subjectivity, the understanding of sensibility must take its point of departure in a genealogy of sensation that is not limited to what is possible in general. Instead it must seek to expand the limits of subjective thought. It is in this perspective that art-as the exploration of differential forces of intensity - becomes central to the production of sensibility and a necessary condition for the act of thinking.

In my view, Deleuze's philosophical unification of aesthetics is remarkable because it gives us theoretical grounds for considering art as a force of production at the center of thought. In this way, the question concerning the relationship between art and other disciplines of thought also becomes relevant. From this perspective, Deleuze considered art to be one of the three great forms of thought, along with science and philosophy. Art is not defined as more creative or productive than other forms of thought but differs in terms of what it produces. While philosophy is the production of concepts and science the production of referential functions, art is the production of percepts and affects and, as such, the exploration of the fundamental encounter of differential sensations. In this way, art is considered as experimentation with the chaotic multiplicity of sensation, creating or exposing new possibilities for structure, intentionality, and meaning. It does not reflect subjectivity but rather produces sensations independent of the perception of objects or the perceiving subject. According to Deleuze, art is what forces sensation, and is in itself "that which only can be sensed" (1968/2004: 182). And if art is what can only be sensed, it follows that art, as a production of thought, is independent of philosophical concepts or the referential functions of science. At the same time, however, what can only be sensed in art is also a presentation of an external condition immanent to something still to be thought as a philosophical concept or a scientific function.

Consequently, while philosophy captures sensation through the creation of a language of concepts, science is deeply involved in creating referential systems that can account for the functions of human perception and affection. Conversely, concepts and functions can serve as the necessary external conditions immanent to what is produced or thought as a sensation in art. In this way, Deleuze argued that 
art, philosophy, and science serve as each others' external conditions immanent to the production of each. As an example, the artist may have great interest in, and utilize, the scientific functions of materials used in a work of art, but what he creates is only art insofar as it produces a sensation independent of the scientific functions of its materials. Likewise, the artist may be interested in exploring a philosophical concept, but if the exploration does not produce a sensation independent of the concept, it fails to leave the philosophical plane.

So the work of art is not an imaginary representation, reflection, or reproduction of any concept or function of subjective sensibility. It does not express qualities of already felt or perceived affections and perceptions, but is instead a preservation of a more primitive level of sensation itself.

\begin{abstract}
Art preserves, and it is the only thing in the world that is preserved. It preserves and is preserved in itself (quid juris?), although actually it lasts no longer than its support and materials - stone, canvas, chemical color, and so on (quid facti?). The young girl maintains the pose that she has had for five thousand years, a gesture that no longer depends on whoever made it. The air still has the turbulence, the gust of wind, and the light that it had that day last year, and it no longer depends on whoever was breathing it that morning... What is preserved - the thing or the work of art-is a bloc of sensation, that is to say, a compound of percepts and affects. Percepts are no longer perceptions; they are independent of a state of those who experience them. Affects are no longer feelings or affections; they go beyond the strength of those who undergo them. Sensations, percepts, and affects are beings whose validity lies in themselves and exceeds any lived. They could be said to exist in the absence of man because man, as he is caught in stone, on the canvas, or by words, is himself a compound of percepts and affects. The work of art is a being of sensation and nothing else: it exists in itself. (Deleuze 1991/1994: 163-164)
\end{abstract}

The aesthetic composition wrests free, or isolates, "a bloc of sensation" independent from the subjective lifeworld, because it can be referred back only to a material structure in paint, canvas, or stone, etc. At the same time, however, the material structure of the work of art does not represent or refer to anything else than what is expressed through it, namely, the forces of sensation. This is why Deleuze argued that the work of art exposes sensation as a relation of external forces immanent to its own production.

We paint, sculpt, compose, and write with sensations. As percepts, sensations are not perceptions referring to an object (reference): if they resemble some- 
thing it is with a resemblance produced with their own methods; and the smile on the canvas is made solely with colors, lines, shadows, and light. (Deleuze and Guattari 1991/1994: 166)

It is in this sense that art can be considered a return to a more primitive level of sensation and, as such, the creation of the sensible or what can be sensed. From this point of view, art can be considered a non-human expression beyond lived experience immanent to the production of subjectivity. As a being of sensation that exists in itself, art exposes us to relations of force outside our subjective being which at the same time become immanent as a genetic force of our subjective lifeworld. Contrary to psychological and phenomenological descriptions of the function of art as a reflection or re-presentation of a deeper meaning, emotion, identity, or essence of human nature, art is a composition of pure sensations. "We are not in the world, we become with the world" (Deleuze and Guattari 1991/1994: 169).

Because the production of sensations goes beyond any representation or organization of already given conditions, there is no such thing as a theory or system of art in Deleuze. As Deleuze and Felix Guattari expressed in Milles Plateaux (1980), "In no way do we believe in a fine-arts system; we believe in very diverse problems whose solutions are found in heterogeneous arts" (1980/1987: 300). The work of art faces problems immanent to its own materials and techniques in producing and presenting sensations. In other words, art cannot be subjugated to a philosophical concept or a scientific function.

For this reason, Deleuze considered artworks to be singular and his philosophy does not present a thinking about art, but is rather an effort to think with art. This is not to say that Deleuze believed that art solves philosophical problems (i.e., that it creates concepts), but since the principles for the composition of the work of art are the same as the genetic principles for the sensation it presents, works of art become that which call for the creation of concepts that correspond to the sensations presented. What interested Deleuze was not the concept of art, which is "a solely nominal concept" (Deleuze and Guattari 1980/1987: 301), but instead art as a practical thought which exposes us to the question of the origin of the being of the sensible or the conditions for what can be sensed. Just as the genesis of the sublime in Kant goes beyond the limits of what can be represented in thought, the 
encounter of intensive or differential forces in art is what expands the limits of what can be sensed.

What is most interesting in Deleuze's perspective on art as a productive force is that it expands the possibilities of subjectivity. In this way, art comprises a process of fundamental learning - a "pedagogy of the senses"-immanent to the relation between sensation and thought. It is from this perspective that the relations between art and subjectivity become an intensely constructive endeavor in Deleuze's engagement with works of art and why he insisted that art is an integral part of the constitution of a thinking subject, which should encourage us to pay attention to art practices.

\section{Art and the Pedagogy of the Senses}

In his book on Bacon, Deleuze wrote:

\footnotetext{
We do not listen closely enough to what painters have to say. They say that the painter is already in the canvas, where he or she encounters all the figurative and probabilistic givens that occupy and preoccupy the canvas. An entire battle takes place on the canvas between the painter and these givens. (1981/2003: 70)
}

If Deleuze wanted to listen to Bacon and his work, it is not because he was interested in his personal history or psychological profile as a means of unraveling an intentionality, meaning, or existential narrative in his paintings. According to Deleuze, the primary "battle" in the practice of painting is not a personal inquiry into emotional states or an effort toward representing an already felt or perceived state in the materials of line and color. Instead, what he found in exemplary form in Bacon's work is an exploration of a practical problem common to all art practice, which "is not a matter of reproducing or inventing forms, but of capturing forces" (40).

\footnotetext{
[F]or a sensation to exist, a force must be exerted on a body, on a point of the wave. But if force is the condition of sensation, it is nonetheless not the force that is sensed, since the sensation "gives" something completely different from the forces that condition it. How will sensation be able to sufficiently turn in on itself, relax or contract itself, so as to capture these forces, and raise itself to its own conditions? It is in this way that music must render nonsonorous forces sonorous, and painting must render invisible forces visible. $(1981 / 2003: 40)$
} 
From this perspective, the question immanent to painting is expressed in Paul Klee's famous formula "[n]ot to render the visible, but to render visible" (40). This does not mean that the painter uses his imagination to invent new forms, colors, or structures. Quite the opposite: since the imagined represents the already given subjective ideas of what can be painted, these givens must be fought or cleared off in order to expose one's self to new sensations. Like the painter Paul Cezanne has suggested, "not a minute of the world passes" that we will preserve if we do not "become that minute" (Deleuze and Guattari 1991/1994: 169). This is why the identity of a subject crea-ting or experiencing works of art cannot serve as a point of departure or be presupposed in an explanation of the composition of sensation in Bacon's paintings. On the contrary: the subjective level of the encounter with Bacon's work is the result of the production or collection of sensations isolated in the material structure.

Consequently, the primary condition for the production of a sensation in the work of art is an escape from, or dissolution of, any given subjective identity or organization. For Deleuze, listening to artists or engaging with art is an exploration of what forces us to become human, or subject, to something. What "makes" us subjects "is not a sensible being, but the being of the sensible" (Deleuze 1968/2004: 176). The necessarily destructive or dissolving element in the encounter with works of art is only effective insofar as it gives rise to a reorganization or production of sensation. To Deleuze, the "good" or effective work of art is something that "forces us to think" in terms of new sensations - to become sensible beings. "Is this not the definition of the percept itself - to make perceptible the imperceptible forces that populate the world, affect us, and make us become?" (Deleuze and Guattari 1991/1994: 182). In other words, by going beyond recognition and representation art becomes an experimental apprenticeship in the forces of sensation.

\section{Bacon and the Body of Sensation}

In the effort to go beyond representation and wrest sensation from any given objective or subjective organization, one of the main obstacles the painter has to fight is the cliché of the figurative, which subjugates the eye to recognition or representation by relating painting to a given object as an illustration or subjective narrative. 
According to Deleuze, modern painting has avoided figurative representations in two ways, by going "toward pure form, through abstraction; or toward the purely figural, through extraction or isolation" (Deleuze 1981/2003: 2). While Jackson Pollock's work can be considered an exemplary expression of radical abstraction, Deleuze found Bacon's work to be an exemplary expression of isolating what the philosopher Jean-François Lyotard has termed the figural (Lyotard 1971). The figural is what goes beyond the rational representation of discourse. In Lyotard's writings, the figural resembles Freud's notion of the unconscious as a primary process appealing to emotional or sensuous experiences beyond the discursive domain of representation. However, in contrast to Lyotard, Deleuze did not relate the figural to a psychological domain, but rather to the production of percepts and affects as a precondition for any emotional or perceptive organization of sensations.

Taking the figural to mean the domain of pure figure, Deleuze went on to describe the battle that unfolds in Bacon's canvases as a neutralization of the primary figuration, which means going beyond the identifying relation between a given object or subjective identity and the 'Figure.' ${ }^{2}$ Bacon's insistence on the Figure isolated from any figurative or narrative association with already given objects or phenomena was what fascinates Deleuze. As Bacon argued, "The story that is already being told between one figure and another begins to cancel out the possibilities of what can be done with paint alone" (Deleuze 1981/2003: 3). By canceling out the structures of already established relations or associated narratives and meanings between figures, Bacon wanted to explore the pure differential relations of force immanent to the composition.

Contrary to the traditional interpretations of Bacon's work, which generally highlight narrative and existential themes of violence, torture, and pain, Deleuze found the most important endeavor to be what Bacon himself described as "record[ing] the fact" (Deleuze 1981/2003: 26) —which in Deleuze's terms becomes an effort to paint the pure sensation. Study after Velazquez's Portrait of Pope Innocent $X$ is an exemplary case of this. Deleuze extrapolated:

\footnotetext{
${ }^{2}$ To emphasize the contrast to the figurative Deleuze writes Figure with a capital F.
} 
When he $[$ Bacon] paints the screaming Pope, there is nothing that might cause horror, and the curtain in front of the Pope is not only a way of isolating him, of shielding him from view; it is rather the way in which the Pope himself sees nothing, and screams before the invisible. Thus neutralized, the horror is multiplied because it is inferred from the scream, and not the reverse. $(1981 / 2003: 27-28)$

What we experience as terrifying in Bacon's painting of the Pope is not a phenomenon or narrative illustration of horror that makes the Pope scream, but the isolation of the intensive force - the violence of sensation - that produces the scream. As Bacon has suggested, he "wanted to paint the scream more than the horror" (27). The isolation of the Figure counteracts the re-presentation of violence as figurative illustration or narrative scene to make visible the violence of sensation in the scream itself. As a result, the portrait renders visible the invisible forces of the body's becoming-scream-"The entire body escapes through the screaming mouth" (20). Put differently, the body of the Pope escapes its representational or illustrative figuration to become an intensive Figure of the production of a scream.

[T]he forces that produce the scream, that convulse the body until they emerge at the mouth as a scrubbed zone, must not be confused with the visible spectacle before which one screams, nor even with the perceptible and sensible objects whose action decomposes and recomposes our pain. If we scream, it is always as victims of invisible and insensible forces that scramble every spectacle, and that even lie beyond pain and feeling. (1981/2003: 42-43)

It is not the visible or extensional bodily movement of a scream that is explored in Bacon's work, but the invisible or intensive forces of sensation directly in the material. According to Deleuze, the technique of figural isolation in Bacon's work exposes a direct encounter between the material and the conditioning forces of sensation. The job of the painter is to make the material pass into sensation. In Bacon's paintings the Figures are not embedded in landscapes or backgrounds from which the form emerges; instead, they are surrounded by uniform and motionless fields of color. As non-figurative zones, these fields do not relate to the Figures as optical depth or distance, but appear on the same plane in an encounter that expresses static or potential violence. "It is the confrontation of the Figure and the field, their solitary wrestling in a shallow depth, that rips the painting away from all narrative but also from all symbolization" (xiv). Isolation is in itself an invisible 
force that neutralizes or cancels out the visible movements of the figures, making it possible for Bacon to wrest free, or produce, intensive forces of sensation - not as moving bodies, but as movements in the bodies, that is, as the intensive condition of movement itself.

Bacon's studies of deformed and twisted bodies do not illustrate constrained or forced bodies; instead, "they are the most natural postures of a body that has been reorganized by the simple force being exerted upon it: the desire to sleep, to vomit, to turn over, to remain seated as long as possible" (Deleuze 1981/2003: 42). The same applies to Bacon's paintings of distorted or agitated faces which do not derive their expressions from movement, "but rather from the forces of pressure, dilation, contraction, flattening, and elongation that are exerted on the immobile head" (41-42).

According to Deleuze, Bacon was centrally occupied with the problem of expressing the elementary forces directly in the material, to make the paint come "across directly on the nervous system" (Deleuze 1981/2003: 26). This is not a new problem in the history of painting, nor an effort limited to Bacon's work.

\footnotetext{
This is a problem of which painters are very conscious. When pious critics criticized Millet [Jean-François Millet, 1814-1875] for painting peasants who where carrying an offertory like a sack of potatoes, Millet responded by saying that the weight common to the two objects was more profound than their figurative distinction. As a painter, he was striving to paint the force of that weight, and not the offertory or the sack of potatoes. And was it not Cézanne's genius to have subordinated all the techniques of painting to this task: rendering visible the folding force of mountains, the germinative force of a seed, the thermic force of a landscape, and so on? (1981/2003: 41)
}

In Bacon's work the problem of capturing forces becomes a radical exploration of the intensive and invisible forces of the body. What science might explore as functions of referential relations in a system of thermodynamics, Bacon explored through intensive relations of line and color as the primary conditions for the pure sensation. In his paintings, what is important is not the referential functions of material structures or the figures' representational relations to narratives, but rather the expression as a fundamental encounter of differential forces - a static violence of sensation - as the invisible conditions beneath the visible organization of the body. This is also why Deleuze insisted that what Bacon painted in his portraits were not faces but heads: "For the face is a structured, spatial organization that conceals the head, 
whereas the head is dependent upon the body, even if it is the point of the body, its culmination" (15).

What is exposed beneath the spatial organization of the body in Bacon's paintings is a formless matter of expression or an incorporeal event of the body. It is in this sense that Bacon's work forms a transcendental empiricism revealing sensations that do not represent an emotional state or objective reference. "As a spectator, I experience the sensation only by entering the painting, by reaching the unity of the sensing and the sensed" (Deleuze 1981/2003: 25). By sustaining or saving a sensation in the material, the painting comes to express an event as an incorporeal effect that forces the body to become. The body happens through sensation.

It is from this perspective that I consider Deleuze's approach to be a remarkable opening toward a new understanding of the relationship between subjectivity and art. Rather than representing subjective sense-experiences or a pre-existing essence of sensibility, art expands our capacity for sensibility through experimentation with intensive still-to-be-actualized forces of the body.

Much like Maurice Merleau-Ponty compared the body to a work of art (Merleau-Ponty 1945/2002: 174), Deleuze suggested in his analysis of Bacon's work that art is a bodily expressiveness, a 'Beingin-the-World'. But contrary to Merleau-Ponty's phenomenological claim that a bodily, pre-reflective intentionality serves as the organizational function in sense experience, Deleuze considered the body to be an assemblage of differential forces with no primary intentional structure or natural identity. The subjective or objective organization of a body is always the result of an immanent production of differential relations. A body of sensation is a body insofar as it encounters other bodies as its differential, intensive elements, or relations, of becoming. Between two actual bodies or different points of the body something undetermined is happening which creates a relation. It is this purely relational image of the body that is captured in Deleuze's immediately strange idea of a 'Body without Organs,' inspired by a poem by the French poet and playwright Antonin Artaud: "The body is the body / it is all by itself / and has no need of organs / the body is never an organism / organisms are the enemies of the body" (quoted in Deleuze and Guattari 1972/1983: 9).

While Merleau-Ponty described art as "an expression of the concrete man" (Merleau-Ponty 1946/1964: 36), capturing the perceived or 
actual body of intentionality in sense experience, Deleuze saw art as the production of a Body without Organs - as a virtual domain freeing sensation from the actual or already established organization. Somewhat schematically, the virtual here refers to the transcendental production, or creative field, that conditions the domain of the actual recognition or identification of what currently is. Virtual does not mean unreal or imaginary, but rather relational, in the sense that an actual state or organization always presupposes the production of a relational possibility. "What we call virtual is not something that lacks reality but something that is engaged in the process of actualization" (Deleuze 1995/2001: 31). The production of a Body without Organs in art is at once a dissolution of the actual understanding of the body, but also the virtual engagement of opening or producing new bodily relations, new ways of becoming, or "new varieties to the world" (Deleuze and Guattari 1991/1994: 175). In this way, the Body without Organs in art is an aesthetic effort to free the concept of the body from its own idea, which resembles what his French colleague Michel Foucault has attempted to do from a historical perspective by arguing that "the soul is the prison of the body" (Foucault 1975/1977: 30). The Body without Organs is at once the dismantling of the self through experimentation, and that which forces a production of new possibilities of subjective sensibility; "It is not at all a notion or a concept but a practice, a set of practices" (Deleuze and Guattari 1980/1987: 149150). To create or find an opening toward forces of sensations still to be sensed, the artist must neutralize or overcome the already given subjective ideas of sensibility and the bodily habits in the act of painting. Deleuze described this as "a preparatory work that belongs to painting fully, and yet precedes the act of painting" (1981/2003: 70). Every painter has his own way of facing this invisible battle, but in Bacon it is captured in a practice of making random or involuntary marks, scrubbing or wiping the canvas or simply throwing paint. "It is as if, in the midst of the figurative and probabilistic givens, a catastrophe overcame the canvas" (71). This catastrophe overcoming the canvas is not only a dissolution or destruction of the given subjective ideas of the painter, it is also the emergence of another world in the material - a body of sensation escaping the constraints of objective or subjective representation. It is through experimentation with these non-representative or non-illustrative traits that the painter composes sensations beyond what is given in subjective experience. In this way, 
according to Deleuze, Bacon's compositions expose a sensibility of the eye beyond the visual domain: "It is a violent chaos in relation to figurative givens, but it is a germ of rhythm in relation to the new order in painting" (72). Rhythm is more profound than vision, hearing, etc., because it is a transcendent force immanent to the exercise of the faculties. "Rhythm appears as music when it invests the auditory level, and as painting when it invests the visual" (30). By relating the Figures to a rhythm, Bacon's paintings go beyond the visual domain of painting and are no longer just a question of seeing, but also of tasting, hearing, or feeling with the eye.

To subjective sensibility, then, what is encountered in Bacon's paintings, according to Deleuze, are not qualities or recognizable objects remembered, felt, or imagined, but that which can only be sensed as a limit of the organized body, forcing the emergence of a new domain. At the limit, the body is both subject and object and it is the same body that gives and receives sensation, forcing an immanent production of sensation. "[I]t is inside the body that something is happening: the body is the source of movement. This is no longer a problem of place, but rather of the event" (Deleuze 1994/1998: 11). In line with Nietzsche's notion of the eternal return, the problem that artists like Bacon grapple with is one of how to sustain the intensity of becoming as an immanent force in being.

\footnotetext{
That the present moment is not a moment of being or of present "in the strict sense", that it is the passing moment, forces us to think of becoming, but to think of it precisely as what could not have started, and cannot finish, becoming. (Deleuze 1962/1983: 48)
}

This is why Deleuze determined the body of sensation as a problem of understanding an event. The body of sensation is an event of that which can only be sensed; an event that forces the body beyond what can be remembered or imagined (i.e., beyond common sense). The Body without Organs does not mean or signify anything, but is created or laid out as an assemblage of points of immanent difference, a "something happening" or a sign that "perplexes the soul" and forces us to think. Many have interpreted this element of Deleuze's thought as a call for radical dissolution of our organized self and subjectivity. However, as Deleuze pointed out, "Dismantling the organism has never meant killing yourself, but rather opening the body to connections that presuppose an entire assemblage" (1980/1987: 160). What 
Deleuze's engagement with art calls for is not a rejection or denial of subjective thought, but rather an experimentation with the relational forces external to the actualization of subjective thought.

In this perspective, the relationship between subjectivity and art in Deleuze's writings is closely related to what Nietzsche once described as an endeavor to stop dragging the past through the future in order "to become who we are" (Nietzsche 1887/2001: 189). From this existential point of view, I find that Deleuze's description of the constructive relationship between subjectivity and art comes across most vividly in his idea of art as a fundamental process of learning.

\section{Proust and the Apprenticeship of Signs}

From the aesthetic perspective of Deleuze's transcendental empiricism, learning is not defined in terms of knowledge or the possession of truth, but rather as the encounter with a problem that raises a faculty to the level of its transcendent exercise, i.e., going beyond recognition and representation. "Learning takes place not in the relation between a representation and an action (reproduction of the Same) but in the relation between a sign and a response (encounter with the Other)" (Deleuze 1968/2004: 25).

A sign should here be understood in terms of Deleuze's theory of sensation, as a symptom which finds its meaning in an existing force, rather than as an appearance or apparition of a given phenomenon. The subjective meaning of a sign is never given, but always the result of an encounter between forces external to the idea of subjectivity. A sign is a sign because we do not know the meaning of it. For this reason, Deleuze's question is not what a sign is, but rather how it is used, discovered, or interpreted. Consequently, Deleuze rejected the idea of a method for learning, but found the source of learning in a "violent training" through fundamental encounters with differential forces immanent to thought. With regards to sensibility, the apprentice "attempts to give birth to that second power which grasps that which only can be sensed" (Deleuze 1968/2004: 205).

It is particularly in relation to the work of Proust that Deleuze unfolds the idea of a learning relationship in the engagement with art. In his book Proust et les Signes, Deleuze wrote:

A work of art is worth more than a philosophical work; for what is enveloped in the sign is more profound than all the explicit significations. What does violence to us is richer than all the fruits of our goodwill or of our conscious 
work, and more important than thought is "what is food for thought." (1964/2000: 30)

According to Deleuze, the central theme in Proust's monumental work, À la recherche du temps perdu (1913-1927), is the narrator's exploration of signs as a fundamental apprenticeship involved in becoming an artist. Contrary to traditional interpretations, Deleuze did not find the unity of $\dot{A}$ la recherche $d u$ temps perdu to be an examination of memory, but rather a "search for truth." This search does include explorations of memories, but only as part of the narrator Marcel's apprenticeship of deciphering involuntary pluralistic signs.

\footnotetext{
Learning is essentially concerned with signs. Signs are the object of a temporal apprenticeship, not of an abstract knowledge. To learn is first of all to consider a substance, an object, a being as if it emitted signs to be deciphered, interpreted. There is no apprentice who is not "the Egyptologist" of something. One becomes a carpenter only by becoming sensitive to the signs of wood, a physician by becoming sensitive to the signs of disease. (1964/2000: 4)
}

In $\grave{A}$ la recherche du temps perdu the narrator is affected by signs that compel him to seek their meaning beyond their immediate appearance. On the one hand, the signs are only there because the narrator attends to them; on the other hand, the reason why he attends to them is that they overwhelm him with feelings that compel him to explore what they mean. In Deleuze's analysis, the narrator explores four different worlds of signs, which correspond to different structures of time. What unifies the different worlds or structures is their formation of systems or collections of signs with intersecting persons, objects, and substances. However, even though the sign systems are unified by these signs, "a man can be skillful at deciphering the signs of one realm but remain a fool in every other case... we discover no truth, we learn nothing except by deciphering and interpreting" (5). Since the plurality of worlds is such that the signs do not appear in the same manner and do not have the same relation to their meaning, Deleuze asserted that signs are both unifying and pluralistic in the production of truth and meaning. Thus, the truth of the sign is beyond significance. The sign is the external force immanent to the production of meaning and truth. It does not signify an already established or stable truth in the world, but it is rather the essence that calls for the production of different worlds. The essential aspect of the search for truth 
does not reside in the involuntary memories, but rather in the learning process that they give rise to: "What is important is that the hero does not know certain things at the start, gradually learns them, and finally receives an ultimate revelation" (3-4).

What the narrator comes to learn in $\dot{A}$ la recherche du temps perdu is that sensuous signs already refer to an ideal essence of sensation incarnated in the material meaning, which is only revealed in the dematerialized or virtual world of art. In this way, Deleuze argued, $\dot{A} l a$ recherche du temps perdu explores or produces different structures of time, corresponding to the different world of signs. In opposition to the dogmatic image of thought represented by common sense, what forces the narrator to think or search for the truth are not natural or voluntary acts, but the events of involuntary sensuous signs that compel him to decipher or unfold their meaning.

The involuntary memories in Proust's work should not, according to Deleuze, be understood as an exposition of reminiscence or of actual events of the past, but rather as a composition of virtual events that force on us a sensibility for that which happens - events that force us to become sensitive or open to different worlds of signs. The event "is always and at the same time something which has just happened and something about to happen; never something which is happening" (Deleuze 1969/2004: 73). The event should not be understood as the active synthesis of present moments exercised by our faculties, but as the passive synthesis of time which is the primary condition for a contemplative mind; "our expectation that "it" will continue, that one or two elements will appear after the other, thereby assuring the perpetuation of our case" (Deleuze 1968/2004: 94-95).

Consequently, the ideal essence of sensuous signs in $\dot{A}$ la recherche du temps perdu expresses a creative composition of events, which folds differential forces of time into being and gives rise to a sensibility for a world of signs.

To be sensitive to signs, to consider the world as an object to be deciphered, is doubtless a gift. But this gift risks remaining buried in us if we do not make the necessary encounters, and these encounters would remain ineffective if we failed to overcome certain stock notions. (Deleuze 1964/2000: 27)

In my view, the understanding of art as an apprenticeship of signs uncovers an existential side to Deleuze's writings that is often overlooked. The description of the relationship between subjectivity and 
art as being "sensitive to signs" might even reveal a normative prescription or ethical imperative to be drawn from art.

\section{Becoming Worthy of the Event}

The normative force of being sensitive to signs is transcendental insofar as sensuous signs do not depend on a subjective or objective being, and empirical insofar as signs or sensations are pluralistic.

To be sensitive to signs or open to new varieties of the world is what Deleuze considered an affirmation of the infinite pluralism of ' $a$ life' - not the individual, or lived, life dependent on a being, but life as the absolute immanent power "carrying with it the events or singularities that are merely actualized in subjects and objects" (Deleuze 1995/2001: 28). In his essay, L'immanence: Une Vie (1995), Deleuze illustrated his image of a life with reference to a scene in Charles Dickens' Our Mutual Friend (1864-1865), in which a disreputable man is brought back to life. Those who eagerly try to save him turn cold once he is brought back to his mean and crude self. What they respond to and want to save is not the individual life of a man held in contempt, nor life in general, but the pre-individual power of a life.

\footnotetext{
Between his life and his death, there is a moment that is only that of $a$ life playing with death. The life of the individual gives way to an impersonal and yet singular life that releases a pure event freed from the accidents of internal and external life, that is, from the subjectivity and objectivity of what happens. (Deleuze 1995/2001: 28)
}

It is this impersonal, infinite force of a life within the event that the artist responds to or saves in the act of creation, and which is actualized in the spectator as perceptions and affections. As Deleuze argued, "Art wants to create the finite that restores the infinite" (Deleuze and Guattari 1991/1994: 197). Though empirically no general rules can be given for these acts of affirmation, the will to free the forces of life imprisoned within its actual organization reveals a normative element, or willing, in art practice.

Although Deleuze never dedicated much of his writing specifically to the question of ethics, in his book, Logique du Sens (1969), he related his ideas of the 'event' to an element of Stoic ethics expressed in the work of the French poet Joe Bousquet, exploring the bodily wounds he incurred as a soldier in the First World War. 
He apprehends the wound that he bears deep within his body in its eternal truth as a pure event. To the extent that events are actualized in us, they wait for us and invite us in. They signal us: "My wound existed before me, I was born to embody it." (Deleuze 1969/2004: 169)

To Deleuze, Bousquet's work expresses an exemplary case of willing the event, as such. To will the event is not to resign and accept what occurs (e.g., war or wounds), but rather to will something yet-to-come inside the event: "the purely expressed" (170). Instead of grasping the external wound inflicted on him by the war as an unjust or unwarranted incident, Bousquet apprehended it as a necessary event making it possible for him to become what he already was through his writing. It is in this sense that there is an ethics of the event or the purely expressed in the genetic relationship between art and subjectivity. "Either ethics makes no sense at all, or this is what it means and has nothing else to say: not to be unworthy of what happens to us" (169). To become worthy of what happens to us is to affirm the impersonal force of a life that does not refer to or represent any given subjective or objective moral principles. The ethical principle of the relationship of fundamental learning between art and subjectivity can be described as an affirmation of the existential grip that sensations or signs can have on us. To become sensitive to the chaotic multiplicity of sensuous signs through art imposes on us an ethical call for a creation or production of meaning and signification that is immanent to what happens. The work of art does not represent something outside its material structure, but is rather a production immanent to its own being as a sensation. In this perspective, becoming worthy of the event primarily implies not to do violence to the forces of sensation that happen to us. Instead, art must appropriate the external forces that are immanent to what happens to us. As described in Deleuze's analysis of Bacon's work, this is a challenging task that requires a battle against the presupposed figurative or narrative structures of our world.

In my view, Deleuze's critique of the traditional aesthetic dualism originating with Kant not only paves the way for a non-representational understanding of art as a production at the center of thought; it also provides valuable insight into the existential grip that art and the world of sensations have on us. Rather than becoming imprisoned, victimized, or categorized by what happens to us, we can operate with the event and make it something else by releasing the pure expressive force within it. This is what painters like Bacon do by exploring the 
expressive force of bodily movements beyond figurative representation, and what writers like Proust do by exploring the forces of time beyond the signs of memory. What Deleuze's reference to Bousquet's work illustrates is that art is a means of attaining the will that events create in us. It is not a question of creating or representing events that have happened or are happening in our lives, but rather an issue of becoming the quasi-cause or operator of the impersonal pre-individual effects of life as it happens to us.

\section{Bibliography}

Deleuze, Gilles. 1953/1991. Empiricism and Subjectivity: An Essay on Hume's Theory of Human Nature (tr. C.V. Boundas). New York, NY: Columbia University Press.

—. 1962/1983. Nietzsche and Philosophy (tr. H. Tomlinson). New York, NY: Columbia University Press.

-. 1963/1984. Kant's Critical Philosophy (tr. H. Tomlinson and B. Habberjam). Minneapolis, MN: University of Minnesota Press.

-. 1964/2000. 'Proust and Signs' (tr. R. Howard) in Theory Out of Bounds, vol. 17. Minneapolis, MN: University of Minnesota Press.

—. 1968/2004. Différence and Repetition (tr. P. Patton). London: Continuum.

—. 1969/2004. The Logic of Sense (tr. M. Lester and C. Stivale). London: Continuum.

-. 1981/2003. Francis Bacon: The Logic of Sensation (tr. D.W. Smith). London: Continuum.

—. 1995/2001. Pure Immanence: Essays on a Life (tr. A. Boyman). New York, NY: Urzone.

— and Felix Guattari. 1972/1983. Anti-Oedipus: Capitalism and Schizophrenia (tr. R. Hurley, M. Seem, and H.R. Lane). Minneapolis, MN: University of Minnesota Press.

— and Felix Guattari. 1980/1987. A Thousand Plateaus: Capitalism and Schizophrenia. (tr. B. Massumi). Minneapolis, MN: University of Minnesota Press.

— and Felix Guattari. 1991/1994. What is Philosophy? (tr. G. Burchell and H. Tomlinson). New York, NY: Columbia University Press. 
Diderichsen, Adam. 2001. 'Fra empirisme til subjektivitet: Deleuze og Hume' in Carlsen, Misha S., Karsten G. Nielsen, and Kim S. Rasmussen (eds) Flugtlinier. Copenhagen: Museum Tusculanum.

Freud, Sigmund. 1910/1964. 'Leonardo da Vinci and a Memory of his Childhood' in The Standard Edition of the Complete Psychological Works of Sigmund Freud, XI: 59-137.

Foucault, Michel. 1975/1977. Discipline and Punish: The Birth of the Prison (tr. A. Sheridan). New York, NY: Pantheon Books.

Hume, David. 1739/1978. A Treatise of Human Nature, 2nd. ed. Oxford: Claredon and Oxford University Press.

Ingarden, Roman. 1965/1973. The Literary Work of Art (tr. G.G. Grabowicz). Evanston, IL: Northwestern University Press.

Kant, Immanuel. 1781/1929. Critique of Pure Reason (tr. N.K. Smith). London: Macmillan Press.

- 1790/1987. Critique of Judgment (tr. W.S. Pluhar). Indianapolis, IN: Hackett Publishing Company.

Lyotard, Jean-François. 1971/2011. Discourse, Figure (tr. A. Hudek and M. Lydon). Minneapolis, MN: University of Minnesota Press.

Merleau-Ponty, Maurice. 1945/2002. Phenomenology of Perception (tr. C. Smith). London and New York, NY: Routledge Classics.

Merleau-Ponty, Maurice. 1946/1964. 'The Primacy of Perception and Its Philosophical Consequences' (tr. J.M. Edie) in The Primacy of Perception and Other Essays on Phenomenological Psychology, the Philosophy of Art, History and Politics. Evanston, IL: Northwestern University Press.

Nietzsche, Friedrich. 1887/2001. The Gay Science (tr. J. Nauckhoff). Cambridge: Cambridge University Press.

Plato. c. 380 B.C./1945. The Republic (tr. F.M. Conford). Oxford: Claredon and Oxford University Press.

Segal, Hanna. 1952. 'A Psychoanalytic Approach to Aesthetics' in International Journal of Psychoanalysis 33: 196-207.

Smith, Daniel W. 1996. 'Deleuze's Theory of Sensation: Overcoming the Kantian Duality' in Patton, Paul (ed.) Deleuze: A Critical Reader. Oxford: Blackwell Publishers. 
Wollheim, Richard. 1987. Painting as an Art. Princeton, NJ: Princeton University Press.

Zeki, Semir. 2004. 'Neural Concept Formation and Art: Dante, Michelangelo, Wagner' in F. Clifford Rose (ed.) Neurology of the Arts: Painting, Music, Literature. 